\title{
A Delphi Investigation to Explain the Voluntary Adoption of XBRL ${ }^{1}$
}

\author{
Enrique Bonsón. University of Huelva, Spain. bonson@uhu.es \\ Virginia Cortijo. University of Huelva, Spain. virginia.cortijo@ decd.uhu.es \\ Tomás Escobar. University of Huelva, Spain. tescobar@uhu.es
}

\begin{abstract}
The objective of this paper is to identify the factors that could have led North-American companies to voluntarily submit their information in XBRL (eXtensible Business Reporting Language) under the XBRL Voluntary Financial Reporting Program (2005-2008). The motivation that led us to carry out this analysis was the fact that, despite the many benefits attributed to XBRL, only 137 companies (out of over 10.000 filers) decided to join the voluntary program issued by the SEC (Securities and Exchange Commission). At this point, we wondered if the SEC should have promoted other benefits to encourage companies to use XBRL. To reach our goal, we conducted a Delphi study. Through this study, we asked a panel of XBRL experts their opinion about the reasons that could have led companies to voluntarily disclose their business information in XBRL. Our results show that, according to experts, factors such as to gain a deeper knowledege of XBRL and to acquire a company image as a pioneer in technology played an essential role in the process of voluntary adoption of the standard.
\end{abstract}

Key words: XBRL; SEC (Securities and Exchange Commission); XBRL Voluntary Financial Reporting Program; Delphi Investigation; adoption; innovation.

\footnotetext{
${ }^{1}$ The authors thank the participants at the $14^{\text {th }}$ World Continuous Auditing and Reporting Symposium, held in Newark, NJ, November 2007 and the $17^{\text {th }}$ Annual Research Workshop on: Artificial Intelligence and Emerging Technologies in Accounting, Auditing and Tax, held in Anaheim, CA, August 2008, for their helpful comments and suggestions on earlier drafts of this paper.
} 


\section{INTRODUCTION}

XBRL (eXtensible Business Reporting Language) is a metalanguage, based on XML, for the electronic communication of business information. Its objective is to improve the disclosure, management and analysis of corporate data, through a unique tagging structure that provides interoperability. In fact, using the framework of XBRL it is possible to facilitate numerous types of reports that can efficiently be parsed by computers (Vasarhelyi and Alles, 2008) and software applications available for the analysis of such information (Silveira et al., 2007). XBRL can be considered as an innovation in the means used by companies to disclose their business information, and it is becoming an Internet business standardization language (Willis, 2007). The adoption of $\mathrm{XBRL}$ is a relevant research topic, of interest for academics and practitioners (Pinsker, 2008).

In the process of diffusion of innovations, it is possible to identify many different factors that may condition its success or failure. These factors can come from outside or inside the company. Sisaye (2003) states that organizations respond to innovations in several ways, depending on the source of uncertainty. The impetus for environmental change is either internally or externally induced. External environmental influences include changes in customer demands, governmental requirements, market competitive forces, or stockholders' desire for better leadership and management styles. Internally, an organization's desire to improve current performance can demand innovations in order to meet or exceed the industry standards for excellent performance.

In the case of XBRL, it is an external factor, the regulatory agencies that, to date made the greatest effort to promote the use of the standard. In Europe, XBRL is being adopted by many regulators as a standard for the reporting of business information (Locke and Lowe, 2007). In the USA, although the 500 largest companies using US GAAP are currently required to submit their business information in $\mathrm{XBRL}^{2}$, there was a voluntary adoption period, when the SEC (Securities and Exchange Commission) published, in February 2005, the XBRL Voluntary Financial Reporting Program on the

\footnotetext{
${ }^{2}$ On December $18^{\text {th }}, 2008$, the SEC voted to require public companies and mutual funds to use interactive data for financial information. The 500 largest companies using US GAAP were required to submit their primary financial statements, notes and financial statement schedules in XBRL for fiscal periods ending in late 2008. The remaining companies using US GAAP will be required to file with interactive data on a phased-in schedule over the next two years. Companies reporting in International Financial Reporting Standards (IFRS) will be required to provide their interactive data reports starting with fiscal years ending on or after June $15^{\text {th }}$, 2011. For more information, please visit: http://www.sec.gov/spotlight/xbrl.shtml.
} 
EDGAR System as a Final Rule (SEC, 2005). According to (Greenstein-Prosch et al., 2008) the adoption of XBRL in the USA was selected because of the size of its economy and highly developed audit profession. Under the XBRL Voluntary Financial Reporting Program, which started on $4^{\text {th }}$ April 2005, registrants were enabled to submit, on a voluntary basis, tagged business information using the XBRL format, as supplementary exhibits to EDGAR filings required by the Securities Exchange Act of 1934 and the Investment Company Act of 1940. The XBRL documents submitted in the voluntary program were supplemental submissions and, therefore, volunteers were still required to file their financial information in HTML or ASCII format.

Although the primary goal of the pilot program was to help the SEC evaluate the usefulness of data tagging and XBRL to registrants, investors, the Commission and the marketplace, it also allowed the participant companies to discover the benefits for themselves from using interactive data. Moreover, the Voluntary Financial Reporting Program allowed investors and analysts to assess new techniques for analyzing interactive data reports submitted to the SEC in the XBRL format.

In order to encourage participation, the Commission staff offered expedited reviews of registration statements and annual reports to those companies that decided to join the Commission's interactive initiative. In addition, the XBRL-US jurisdiction developed many educational and training resources to help companies to understand the current problems associated with the traditional business reporting models, and how the benefits of XBRL can overcome some of these deficiencies.

In spite of these benefits, by December 2008, only 137 companies (out of over 10.000 filers) had decided to participate in the Commission's program. Maybe, the advantages stressed by the SEC were not perceived by companies as sufficient reason to adopt the standard. At this point, we wonder if it would have been appropriate for the SEC to promote other factors to encourage more companies to join the XBRL Voluntary Financial Reporting Program. To answer this question, we performed a Delphi study; we asked XBRL experts their opinion about the reasons that could have led companies voluntarily to submit supplemental tagged financial information in XBRL. Our results show that factors such as to gain a deeper knowledge of XBRL, to acquire a company image as a pioneer in technology, and to improve the firm's reputation in the capital markets, played a significant role in the process of voluntary adoption of the standard.

With this study, we attempt to contribute to research on the voluntary adoption of innovations by companies. Also, conclusions drawn in this paper can be considered when 
analysing the voluntary adoption of the XBRL standard in other geographical areas. The remainder of this paper is organized as follows. Section 2 describes the methodology and results. Section 3 discusses the main implications of the results we obtained and section 4 concludes.

\section{METHODOLOGY AND RESULTS}

To identify the factors that could have led companies to voluntarily use XBRL under the Commission's interactive initiative, we conducted a Delphi study. Through this study, we asked XBRL experts, from the academic and professional fields, their opinion about the factors that could have led companies voluntarily to submit tagged business information in XBRL format. Our final goal was to identify additional reasons that could have been incorporated by the SEC into its arguments to get a greater participation in the Voluntary Financial Reporting Program and, therefore, contribute to expanding the voluntary use of the XBRL standard.

The Delphi technique, developed by the Rand Corporation in the 1950's, can be defined as a systematic and iterative process by which the opinions of a group of experts are obtained, re-considered and modified with the purpose of reaching a consensus view among those experts, if it is possible (Dalkey and Helmer, 1963). This methodology can assist in many different kinds of research; it can be used as a technique for forecasting future events or for obtaining a consensus estimation of future trends (Brancheau et al., 1996; Czinkota and Ronkainen, 1997; Lynch et al., 1994). It can also be used as a mechanism to facilitate the analysis of complex social realities (Buck et al. 1993) or the impact of innovations in various fields (Torres et al., 2005; Addison, 2003; BaldwinMorgan, 1993). In addition, the Delphi technique can assist in decision-making and can even contribute to conferring greater significance and impact on a decision reached by using that technique (Van Eynde and Tucker, 1997; Khorramshagol and Moustakis, 1988).

In this study, we use the Delphi technique to perform a more in-depth analysis of the factors that could influence the process of adoption of a particular innovation, XBRL, which was being advanced by a governmental regulatory organization (the SEC), through its XBRL Voluntary Financial Reporting Program. This study involved asking a panel of XBRL experts, recruited from among qualified academics and professionals, to give their opinion on the reasons that could have led companies voluntarily to submit supplemental tagged business information in XBRL, under the XBRL Voluntary Financial Reporting 
Program. The panelists who participated in this study can be considered XBRL experts because they are involved in the development, application and diffusion of the standard; they are academics who are conducting their research on XBRL, professionals who work in companies dedicated to the development of XBRL applications, and members of XBRL International.

\begin{tabular}{|c|l|}
\hline 1 & To acquire a company image as a pioneer in technology. \\
\hline 2 & $\begin{array}{l}\text { To have the opportunity of influencing the future development of this new technology and } \\
\text { directing it towards your objectives. }\end{array}$ \\
\hline 3 & To gain a deeper knowledge of XBRL to be able to benefit from all its advantages. \\
\hline 4 & To become familiar with XBRL in order to install it later at the transactional level. \\
\hline 5 & To facilitate relationships with the regulatory authorities, in particular with the SEC. \\
\hline 6 & To obtain faster reviews by the SEC. \\
\hline 7 & To improve the company's image in the financial markets and thus gain more support. \\
\hline 8 & To improve the company's image in the "information society". \\
\hline 9 & To compete with other companies that are applying XBRL through the SEC's Voluntary Program. \\
\hline 10 & To improve the quality of financial information provided to the various users of this information. \\
\hline 11 & XBRL enables the production of personalized reports. \\
\hline 12 & $\begin{array}{l}\text { XBRL enables the production of new reports that include information of both financial and non- } \\
\text { financial character. }\end{array}$ \\
\hline 13 & XBRL facilitates comparability between the different parts that comprise the company. \\
\hline 14 & XBRL facilitates comparability between companies. \\
\hline 15 & XBRL makes financial information easier to understand. \\
\hline 16 & XBRL facilitates the analysis of company accounts. \\
\hline 17 & Because it is a metalanguage, XBRL allows search and consultation tools to be used. \\
\hline 18 & Errors are avoided because the process of data entry is simplified. \\
\hline 19 & Time is saved in the preparation of financial information. \\
\hline 20 & Time is saved in accessing financial information. \\
\hline 21 & The costs of preparing financial information are reduced. \\
\hline 22 & The costs of accessing financial information are reduced. \\
\hline 23 & The costs of issuing capital are reduced. \\
\hline 24 & Greater transparency in information disclosure is achieved. \\
\hline
\end{tabular}

Table 1. Motivations that may have led companies to participate in the XBRL Voluntary Financial Reporting Program

The Delphi technique consists of a sequence of phases. First, we sent a questionnaire to the panel of XBRL experts. In this questionnaire, experts were asked to rate on a scale from 0 to $10^{3}$ a number of reasons that could have led companies to participate in the

\footnotetext{
${ }^{3}(0=$ not important to the company; $10=$ extremely important to the company).
} 
XBRL Voluntary Financial Reporting Program. To facilitate the task of the experts, we gave them a list of possible reasons (Table 1), arranged randomly. We extracted these reasons from a review of the literature on the process of adoption of innovations. In addition, we included a final open question in the first questionnaire to allow XBRL experts to add any other reason that, being important for them, had not been listed in the questionnaire $^{4}$.

Our first questionnaire was e-mailed to 58 experts, both academics and professionals, together with a covering letter to explain them the purpose of our research and invite them to participate in the study. The rate of response to the first questionnaire was $50 \%$, which provided a total of 29 usable responses. Of these 29 experts, 16 were academics researching XBRL and 13 were professionals who were working in companies involved in the development and use of the standard ( 7 of them were members of XBRL International).

\begin{tabular}{|c|l|}
\hline 1 & $\begin{array}{l}\text { XBRL can walk users through the complexities of elaborating financial information. The ability to } \\
\text { leverage XBRL metadata, including business rules, reduces the training and/or knowledge required to } \\
\text { create a financial statement. }\end{array}$ \\
\hline 2 & $\begin{array}{l}\text { The ability to leverage XBRL metadata, including business rules, allows better adherence to rules and } \\
\text { the complex disclosure and presentation requirements. }\end{array}$ \\
\hline 3 & $\begin{array}{l}\text { The ability to leverage XBRL metadata, including business rules, allows better reuse of financial } \\
\text { information and better integration with software applications. }\end{array}$ \\
\hline 4 & $\begin{array}{l}\text { Companies want to provide feedback on how well the technology works to ensure that it is a great } \\
\text { solution for all companies, encouraging other companies to collaborate as well. }\end{array}$ \\
\hline 5 & Companies want to put their name behind the program in order to help make the program successful. \\
\hline 6 & $\begin{array}{l}\text { Firm managers aim to be viewed by market participants and regulators as possessing high integrity. } \\
\text { Furthermore, the increased transparency facilitated by XBRL allows firm managers to send signals to } \\
\text { the marketplace regarding their effort to disclose all relevant information on a timely basis. }\end{array}$ \\
\hline
\end{tabular}

Table 2. Additional reasons that experts suggested in the first questionnaire

Once the first round of responses was analyzed, we prepared the second questionnaire, including the additional reasons that some panelists had suggested (Table 2). We also provided statistical information about the overall results of the first round (the mean and median values, the first and third quartiles and the interquartile range of every answer). In the second questionnaire, we asked the same set of experts to revise their initial answers, if they wished, and to comment on any first round responses that fell

\footnotetext{
${ }^{4}$ According to Scheele (2002), in this type of Delphi survey, the initial questions should not be defined exclusively by the coordinators of the study, but also by the panel of experts.
} 
outside the interquartile range of replies, since our objective was to assess whether they had changed any of their opinions after having considered the aggregate answers of all respondents.

The second round Delphi survey produced 15 usable responses (52\% of the 29 first round respondents completed the second round). Of these 15 experts, 10 were academics researching XBRL and 5 were working in companies involved in the development and use of the standard (3 of them were members of XBRL International). The final-round results are shown in Tables $3 a$ and $3 b$.

\begin{tabular}{|c|c|c|c|}
\hline Rank & Reason & Mean & $\begin{array}{l}\text { Standard } \\
\text { Deviation }\end{array}$ \\
\hline 1 & $\begin{array}{l}\text { To gain a deeper knowledge of XBRL to be able to benefit from all its } \\
\text { advantages }\end{array}$ & 7.067 & 1.624 \\
\hline 2 & To acquire a company image as a pioneer in technology & 6.733 & 2.251 \\
\hline 3 & $\begin{array}{l}\text { The ability to leverage XBRL metadata, including business rules, } \\
\text { allows better reuse of financial information and better integration with } \\
\text { software applications }\end{array}$ & 5.933 & 2.890 \\
\hline 4 & $\begin{array}{l}\text { To improve the company's image in the financial markets and thus gain } \\
\text { more support }\end{array}$ & 5.933 & 2.052 \\
\hline 5 & Greater transparency in information disclosure is achieved & 5.867 & 2.997 \\
\hline 6 & $\begin{array}{l}\text { To become familiar with XBRL in order to install it at the transactional } \\
\text { level }\end{array}$ & 5.867 & 1.457 \\
\hline 7 & $\begin{array}{l}\text { To improve the quality of financial information provided to the various } \\
\text { users of this information }\end{array}$ & 5.733 & 2.549 \\
\hline 8 & The costs of accessing financial information are reduced & 5.667 & 2.637 \\
\hline 9 & $\begin{array}{l}\text { The ability to leverage XBRL metadata, including business rules, } \\
\text { allows better adherence to rules and the complex disclosure \& } \\
\text { presentation requirements }\end{array}$ & 5.600 & 2.746 \\
\hline 10 & To obtain faster reviews by the SEC & 5.600 & 1.502 \\
\hline 11 & $\begin{array}{l}\text { Firm managers aim to be viewed by market participants and regulators } \\
\text { as possessing high integrity. Furthermore, the increased transparency } \\
\text { facilitated by XBRL allows firms to send a signal to the marketplace } \\
\text { regarding their effort to disclose all relevant information on a timely } \\
\text { basis }\end{array}$ & 5.467 & 2.031 \\
\hline 12 & $\begin{array}{l}\text { To have the opportunity of influencing the future development of this } \\
\text { new technology and directing it towards your objectives }\end{array}$ & 5.400 & 2.586 \\
\hline 13 & To improve the company's image in the "information society" & 5.400 & 2.354 \\
\hline 14 & $\begin{array}{l}\text { To facilitate relationships with the regulatory authorities, in particular } \\
\text { with the SEC }\end{array}$ & 5.333 & 2.289 \\
\hline
\end{tabular}




\begin{tabular}{|c|c|c|c|}
\hline Rank & Reason & Mean & $\begin{array}{l}\text { Standard } \\
\text { Deviation }\end{array}$ \\
\hline 15 & XBRL facilitates comparability between companies & 5.267 & 2.939 \\
\hline 16 & $\begin{array}{l}\text { XBRL facilitates comparability between the different parts that } \\
\text { comprise the company }\end{array}$ & 5.133 & 2.800 \\
\hline 17 & Time is saved in accessing financial information & 5.067 & 2.631 \\
\hline 18 & Errors are avoided because the process of data entry is simplified & 5.067 & 2.314 \\
\hline 19 & $\begin{array}{l}\text { Companies want to provide feedback on how well the technology } \\
\text { works to ensure that it is a great solution for all companies; } \\
\text { encouraging other companies to collaborate as well. }\end{array}$ & 5.000 & 2.478 \\
\hline 20 & $\begin{array}{l}\text { Because it is a metalanguage, XBRL allows search and consultation } \\
\text { tools to be used }\end{array}$ & 4.933 & 2.865 \\
\hline 21 & XBRL makes financial information easier to understand & 4.867 & 3.091 \\
\hline 22 & XBRL facilitates the analysis of company accounts & 4.800 & 2.678 \\
\hline 23 & $\begin{array}{l}\text { Companies want to put their name behind the program in order to help } \\
\text { make the program successful }\end{array}$ & 4.800 & 1.859 \\
\hline 24 & Time is saved in the preparation of financial information & 4.733 & 2.604 \\
\hline 25 & The costs of preparing financial information are reduced & 4.400 & 2.384 \\
\hline 26 & XBRL enables the production of personalized reports & 4.000 & 1.813 \\
\hline 27 & $\begin{array}{l}\text { XBRL enables the production of new reports that include information } \\
\text { of both financial and non-financial character }\end{array}$ & 4.000 & 1.964 \\
\hline 28 & The costs of issuing capital are reduced & 3.867 & 2.503 \\
\hline 29 & $\begin{array}{l}\text { XBRL can walk users through the complexities of elaborating financial } \\
\text { information. The ability to leverage XBRL metadata, including } \\
\text { business rules, reduces the training and/or knowledge required to create } \\
\text { a financial statement. }\end{array}$ & 3.400 & 2.530 \\
\hline 30 & $\begin{array}{l}\text { To compete with other companies that are applying XBRL through the } \\
\text { SEC's Voluntary Program }\end{array}$ & 3.133 & 1.959 \\
\hline
\end{tabular}

Table 3b. Results for Round Two, reasons 15 to 30.

We employed a two-round Delphi method because, at this point, we had collected enough information to draw conclusions. Previous studies used three rounds; however, the number of rounds is somewhat flexible (Delbeq et al., 1975) and, although this technique is used to find consensus views, this is not its ultimate goal, and consensus does not have to be found.

\section{DISCUSSION}

This study allows us to identify the reasons that, according to XBRL experts, could have persuaded companies to use XBRL under the Voluntary Financial Reporting Program. The fact that the SEC did not promote the total number of these reasons could 
explain why the diffusion of XBRL did not happened as quickly and successfully as had been foreseen.

According to XBRL experts, the strongest motivation for companies to decide to participate in the Commission's interactive initiative was to gain a deeper knowledge of XBRL in order to be able to benefit from all its advantages. In fact, as some of the panelists stated, this motivation could be considered as the underlying root reason for all the others.

The second reason with greater weight was the desire of companies to acquire a corporate image as a pioneer in technology, through participation in the Voluntary Financial Reporting Program. In this sense, some experts explained that the Commission's program provided an easy means of gaining publicity, and that being a pioneer with information technologies is an important "bragging right" for many of the companies participating. Along these lines, another expert stated: "I believe that there is an essential difference between adopting XBRL as an in-house technology and the reasons why companies will voluntarily disclose their financials with the SEC. The latter is more of a signaling issue, while the former is more an efficiency issue".

These comments show that, according to XBRL experts, one the main reasons that could have led companies to participate in the Voluntary Financial Reporting Program was the desire to improve their reputation. However, the technical advantages of XBRL may have been the reason why companies could have decided to use the standard internally, and this may have indirectly leaded them to join the program. This is the rationale that supports the third reason, which is clearly related to technology: "the ability to leverage XBRL metadata, including business rules, allows better re-use of financial information and better integration with software applications".

The fourth reason argued by the experts was that "companies may join the Voluntary Financial Reporting Program in order to improve their image in the financial markets and thus gain more support". In fifth rank, with identical mean scores, there are two reasons: the first one is related to the greater transparency in information that can be achieved with XBRL while the second one states that participation in the Voluntary Financial Reporting Program gives companies the possibility to become familiar with XBRL, in order to install it at the transactional level. On this point, the SEC declares that registrants that use XBRL internally will improve their internal reporting process. This is the first of the benefits of XBRL that the SEC stresses to promote the participation in the program, which appears in the ranking based on the opinions of XBRL experts. However, the rest 
of the SEC's reasons, have lower rankings; table 4 shows the assessment made by the panel of experts of the benefits of XBRL promoted by the SEC, according to responses to the motivations listed in the questionnaire (third column).

These results show that the factors stressed by the SEC to stimulate the participation in the Voluntary Financial Reporting Program were not perceived as sufficiently important reasons for making the decision of joining the program.

\begin{tabular}{|c|c|c|c|}
\hline Rank & Benefits (SEC) & Reason (Questionnaire) & Mean \\
\hline 6 & $\begin{array}{l}\text { Registrants that use XBRL internally will have } \\
\text { improved internal reporting process. }\end{array}$ & $\begin{array}{l}\text { To become familiar with XBRL } \\
\text { in order to install it at the } \\
\text { transactional level }\end{array}$ & 5.867 \\
\hline 8 & $\begin{array}{l}\text { XBRL will lower the cost of accessing to } \\
\text { financial information }\end{array}$ & $\begin{array}{l}\text { The costs of accessing financial } \\
\text { information are reduced }\end{array}$ & 5.667 \\
\hline 15 & $\begin{array}{l}\text { XBRL-tagged data will encourage companies to } \\
\text { provide comparable information. }\end{array}$ & $\begin{array}{l}\text { XBRL facilitates comparability } \\
\text { between companies }\end{array}$ & 5.267 \\
\hline 18 & $\begin{array}{l}\text { XBRL may make the tagging process more } \\
\text { accurate }\end{array}$ & $\begin{array}{l}\text { Errors are avoided because the } \\
\text { process of data entry is } \\
\text { simplified }\end{array}$ & 5.067 \\
\hline 22 & $\begin{array}{l}\text { XBRL will free resources from manual reporting } \\
\text { to do work that really adds value to the company. }\end{array}$ & $\begin{array}{l}\text { XBRL facilitates the analysis of } \\
\text { company accounts }\end{array}$ & 4.800 \\
\hline 25 & $\begin{array}{l}\text { XBRL will lower the cost of producing financial } \\
\text { information }\end{array}$ & $\begin{array}{l}\text { The costs of preparing financial } \\
\text { information are reduced }\end{array}$ & 4.400 \\
\hline 28 & $\begin{array}{l}\text { Tagged information has the potential to increase } \\
\text { analyst coverage and investor interest in a } \\
\text { registrant's securities; this could increase } \\
\text { liquidity in the market and lower the cost of } \\
\text { capital }\end{array}$ & $\begin{array}{l}\text { The costs of issuing capital are } \\
\text { reduced }\end{array}$ & 3.867 \\
\hline
\end{tabular}

Table 4. Assessment of the benefits promoted by the SEC

\section{FINAL CONSIDERATIONS}

The diffusion of innovations is a complex process. It depends on many different factors that condition both the speed and the scope of the process. While it seems obvious that technical factors can speed up the diffusion of innovations, research has identified other factors, institutional variables, which can also have a significant impact on this process.

This study analyses the process of diffusion of the XBRL standard for the disclosure of business information in the USA. This process can be divided into three different periods. From July 2000 until September 2004, the technical advantages of XBRL were 
stressed to promote its adoption. However, the difficulties in demonstrating the potential benefits of XBRL until its full adoption, deterred companies from using the standard to prepare their business information. As a consequence, during the first period, a true application of the standard was not achieved.

Since September 2004, when the SEC published the Proposed Rule 33-8496, and the later Final Rule in February 2005, which issued the XBRL Voluntary Financial Reporting Program, there was a significant increase in the number of companies that decided to use XBRL for disclosing their business information in the USA. The fact that the SEC took a firm position in favor of XBRL, made an investment of \$54 million to support that position, and offered greater visibility to the firms that use the standard, seems to have encouraged companies to adopt the innovation. But, despite the increase in the number of firms that decided to use XBRL, by December 2008, only 137 companies (out of over 10.000 filers) had joined the Commission's program. At this point, we wondered if the SEC should have promoted other benefits to encourage companies to use XBRL.

The Delphi study we performed showed that factors such as to gain a deeper knowledge of XBRL, to acquire a company image as a pioneer in technology, and to improve the firm's reputation in the capital markets, played a significant role in the process of voluntary adoption of the standard. However, these factors combined with the reasons argued by the SEC to promote the voluntary use of XBRL were not enough to reach the massive adoption of the standard. Consequently, on $18^{\text {th }}$ December, 2008, the SEC voted to require public companies and mutual funds to use interactive data for financial information. Therefore, in December 2008, a new stage of the process of XBRL adoption began. In this third period, the 500 largest companies using US GAAP are required to submit their primary financial statements, notes and financial statement schedules in XBRL for fiscal periods ending in late 2008. The remaining companies using US GAAP are required to file with interactive data on a phased-in schedule over the next two years ${ }^{5}$. With this initiative, the SEC confirms what had already happened in other countries such as Spain: until the use of XBRL was compulsory, a massive application of the standard was not achieved.

\footnotetext{
${ }^{5}$ Companies reporting in IFRS will be required to provide their interactive data reports starting with fiscal years ending on or alter June 15th, 2011.
} 


\section{REFERENCES}

ADDISON, T. (2003): "E-commerce project development risks: evidence from a Delphi survey", International Journal of Information Management, vol. 23: 25-40.

BALDWIN-MORGAN, A. (1993): "The impact of expert system audit tools on auditing firms in the year 2001: a Delphi investigation", Journal of Information Systems, vol. 7, n. 1: $16-34$.

BRANCHEAU, J.C.; JANZ, B.D.; WETHERBE, J.C. (1996): "Key issues in information systems and management: 1994-95 SIM Delphi results", MIS Quarterly, vol. 20, n. 2: $225-42$.

BUCK, A.J.; GROSS, M.; HAKIN, S.; WEINBLATT, J. (1993): "Using the Delphi process to analyze social policy implementation: a post hoc case from vocational rehabilitation", Policy Sciences, vol. 26, n. 4: 271-88.

CZINKOTA, M.; RONKAINEN, I. (1997): "International business and trade in the next decade”, Journal of International Business Studies, vol. 28, n. 4: 827-44.

DALKEY, N.; HELMER, O. (1963): "An experimental application of the Delphi method to the use of experts", Management Science, vol. 9, n. 3: 458-67.

DELBECQ, A.; VAN DE VEN, A.; GUSTAFSON, D. (1975): Group Techniques for Program Planning: A Guide to Nominal Group and Delphi Processes, Scott Foresman, Glenview, IL.

GREENSTEIN-PROSCH, M.; MCKEE, T.E.; QUICK, R. (2008): “A Comparison of the Information Technology Knowledge of United States and German Auditors", The International Journal of Digital Accounting Research, vol. 8: 45-79.

KHORRAMSHAGOL, R.; MOUSTAKIS, V.S. (1988): "Delphi Hierarchy Process (DHP): a methodology for priority setting derived from the Delphi method and analytical hierarchy process", European Journal of Operational Research, vol. 37: 347-54.

LOCKE, J.; LOWE, A. (2007): "XBRL: An (Open) Source of Enlightenment or Disillusion?", European Accounting Review, vol. 16, n. 3: 585-623.

LYNCH, M.; IMADA, S.J.; BOOKBINDER, J.H. (1994): "The future of logistics in Canada: a Delphi based forecast", Logistic and Transportation Review, vol. 30, n. 1: 95-112. 
PINKSER, R. (2008): “An Empirical Examination of Competing Theories to Explain Continuous Disclosure Technology Adoption Intentions Using XBRL as the Example Technology", The International Journal of Digital Accounting Research, vol. 8: 81-96.

SCHEELE, D.S. (2002): "Reality construction as a product of Delphi interaction", in The Delphi Method: Techniques and Applications, H.A. Linstone; M.Turoff (Ed.), available at: http://is.njit.edu/pubs/delphibook (accessed on 15th March 2007)

SEC (2005): XBRL Voluntary Financial Reporting Program on the Edgar System. Securities and Exchange Commission, Financial Accounting Standards Board, Norwalk, CT, available at www.sec.gov/rules/final/33-8529.htm (accessed on 19 December 2007).

SILVEIRA, C.; ABREU, R.; FÁTIMA, D. (2007): "From an Object-Oriented Approach to the Financial Reporting: An Open Architecture", The International Journal of Digital Accounting Research, vol. 7: 1-25.

SISAYE, S. (2003): "Adaptive institutional change strategies in management control systems: activity based costing as administrative innovation", Advances in Management Accounting, vol. 11: 251-85.

TORRES, L.; PINA, V.; ROYO, S. (2005): "E-government and the transformation of public administrations in EU countries. Beyond NPM or just a second wave of reforms?", Online Information Review, vol. 29, n. 5: 531-53.

VAN EYNDE, D.F.; TUCKER, S.L. (1997): “A quality human resource curriculum: recommendations from leading senior HR", Human Resource Management, vol. 36, n. 4: 397-408.

VASARHELYI, M.A.; ALLES, M.G. (2008): "Reengineering Business Reporting Creating a Test Bed for Technology Driven Reporting", The International Journal of Digital Accounting Research, vol. 8: 97-135.

WILLIS, M. (2007): "Improving Investor Communications and Analysis via Standardization", The International Journal of Digital Accounting Research, vol. 7: 151163. 